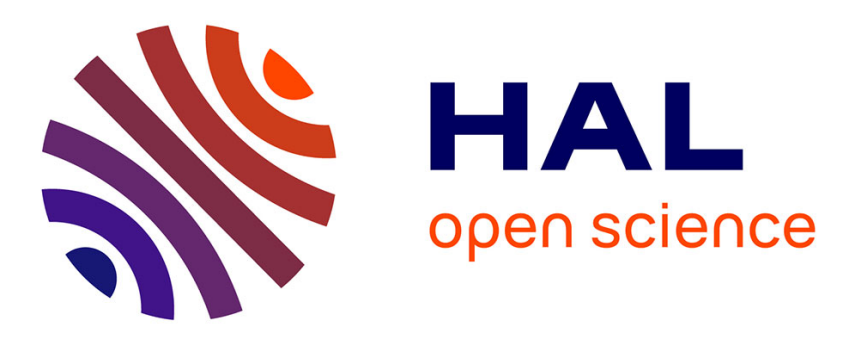

\title{
Metallic complexes of hydroxylated derivatives of vitamin D3.
}

X.T. Do, A.-S. Coquin, S. Megdad, Mustayeen A. Khan, G. Bouet.

\section{To cite this version:}

X.T. Do, A.-S. Coquin, S. Megdad, Mustayeen A. Khan, G. Bouet.. Metallic complexes of hydroxylated derivatives of vitamin D3.. Vitamin D, A Pluripotent Steroid Hormone, May 1994, Orlando, Florida, United States. 10.1515/9783110882513-014 . hal-03193547

\section{HAL Id: hal-03193547 \\ https://univ-angers.hal.science/hal-03193547}

Submitted on 8 Apr 2021

HAL is a multi-disciplinary open access archive for the deposit and dissemination of scientific research documents, whether they are published or not. The documents may come from teaching and research institutions in France or abroad, or from public or private research centers.
L'archive ouverte pluridisciplinaire HAL, est destinée au dépôt et à la diffusion de documents scientifiques de niveau recherche, publiés ou non, émanant des établissements d'enseignement et de recherche français ou étrangers, des laboratoires publics ou privés. 


\title{
METALLIC COMPLEXES OF HYDROXYLATED DERIVATIVES OF VITAMIN $D_{3}$
}

\author{
X.T. DO*, A-S COQUIN*, S. MEGDAD**, M.A. KHAN** AND G. BOUET**
} Laboratoires de Physiologie* et de Chimie de Coordination"* Faculté de Pharmacie, Université d'Angers, F- 49100 Angers (France).

As far as we know, very few complexes have been studied using vitamin D or its hydroxylated derivatives as ligands. Barton and Patin used vitamin $D_{2}$ (ergocalciferol) to obtain iron carbonyl complexes through the trien system (1) and the same authors synthetized palladium chloride $\pi$ allyl complexes with calciferol, ergosterol, 3-epi-ergosterol and 7-dehydrocholesterol (2). In addition Qitao, using a $\mathrm{pH}$ metric method at a constant ionic strength $\left(0.1\right.$ mol. $\left.\left.\right|^{-1}\right)$ concluded that both $\mathrm{Ca}$ " and $\mathrm{Cd}$ " give 1:1 (metal:ligand) and 1:2 complexes (3).In this paper, we describe the $\mathrm{CoCl}_{2}: \mathrm{Vit}_{3}$ (or its hydroxylated derivatives) system in aqueous $\mathrm{NaCl}$ solutions $\left(9 \mathrm{g.} \mathrm{l}^{-1}\right)$ at constant ionic strength of $0.3 \mathrm{~mol} . \mathrm{I}^{-1}$. The choice of the cobalt as centre of coordination was made because its cation is the central element in vit $B_{12}$. In order to determine the composition of the occurring complexes we have applied the continuous variations method for qualitative determinations (4).

\section{Experimental}

It is well known that vit. $D_{3}$ and analogues are not very stable when exposed to air or light, consequently, the solutions were always prepared just before recording spectra. The vit. $D_{3}$ or its hydroxylated derivatives were first dissolved in methanol $\left(2.5 \mathrm{~cm}^{3}\right)$ under dinitrogen atmosphere and further diluted in $50 \mathrm{~cm}^{3}$ of sodium chloride solution. The cobalt solution was prepared in the same way in order to obtain the same molarity of the two solutions. The spectra were recorded at $25^{\circ} \mathrm{C}(298 \mathrm{~K})$ with a Hitachi U 2000 spectrophotometer.

\section{$\underline{\text { Results and discussion }}$}

\section{Composition of the complexes}

To draw the curves for the continuous variations we have determined the corrected absorbance $A_{\text {corr }}(5,6)$ in order to keep only the spectrum of the complex species ( $m$ is related to the metal and $v$ to the cholecalciferol) :

$A_{c o r r}=A_{\exp }-\left(C_{m} \varepsilon_{m}+C_{v} \varepsilon_{v}\right)$ (where $\varepsilon$ is the molar extinction coefficient) As the aqueous solutions of cobaltous chloride present a very weak absorption in the visible region because of their low molarity, it can be assumed that $\varepsilon_{m} \approx 0$. Thus the chosen wavelengths were around the maximum absorption band of the vitamin $D_{3}$ or its derivatives. The figure 1 presents the curves obtained with $24 R, 25$-dihydroxyvitamin $D_{3}$. All the ligands give $1: 1$ and 1:4 type complexes.

\section{Estimated overall stability constants}

The overall stability constants at $298 \mathrm{~K}$ were estimated assuming that at a given wavelength, the observed absorption is due to the free ligand only. The logarithmic values of the overall stability constants, $\log \beta$ are tabulated below. 


\begin{tabular}{|c|c|c|c|}
\hline LIGAND & $\lambda_{\max }(\mathrm{nm})$ & $1: 1$ type & $1: 4$ type \\
\hline $25(\mathrm{OH}) \mathrm{D}_{3}$ & 250 & $4.7 \pm 0.2$ & \\
\hline $1 \alpha, 25(\mathrm{OH})_{2} \mathrm{D}_{3}$ & 283 & $3.6 \pm 0.4$ & $16.7 \pm 0.2$ \\
\hline $24 R, 25(\mathrm{OH})_{2} \mathrm{D}_{3}$ & 301 & $4.3 \pm 0.4$ & $17.3 \pm 0.4$ \\
\hline
\end{tabular}

\section{Proposed structures}

As the complex species are soluble in aqueous solutions, the hydrophilic moiety of the ligands should be in the outer part of the complex. Therefore, the only coordinating atom is the oxygen of the $\mathrm{OH}$ in 3 , as shown in figure 2.

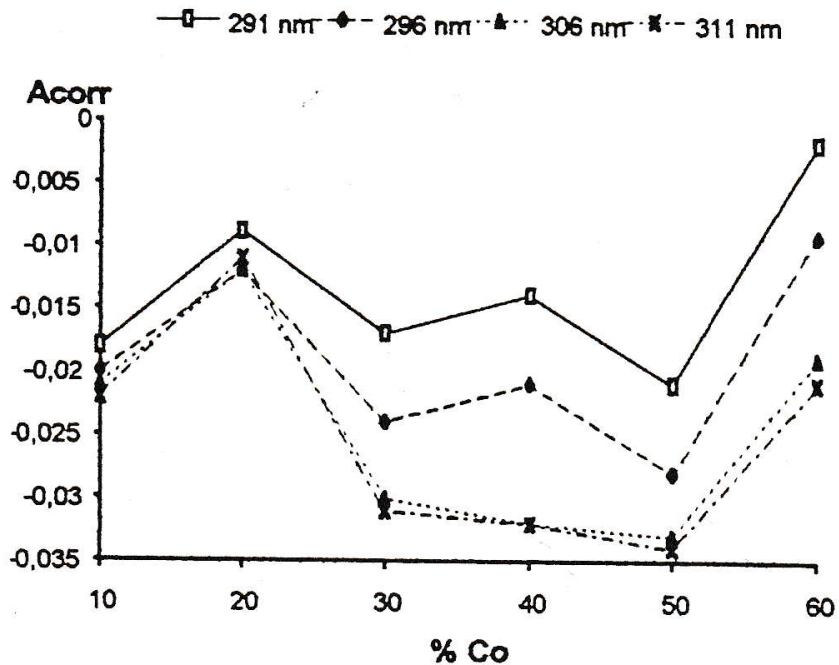

Fig. 1 : Continuous variations for 24,25 $(\mathrm{OH})_{2} \mathrm{D}_{3}$.

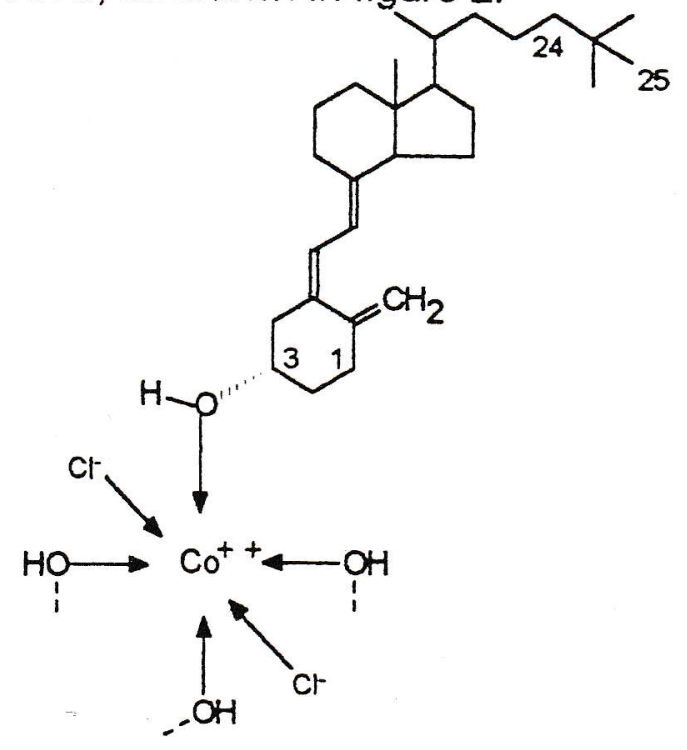

Fig. 2 : Proposed structure for $1: 4$ type complex.

\section{$\underline{\text { References }}$}

1 - Barton, D.H.R. and Patin, H. (1976) J. Chem. Soc., Perkin 1, 829-831.

2 - Barton, D.H.R. and Patin, H. (1977) J. Chem. Soc., Chem. Comm., 799-800.

3 - Qitao, L., Yi, L. and Feng, Z.(1989) Polyhedron, 8(15), 1953-1956.

4 - Woldbye, F., (1955) Acta Chem. Scand., 9, 299-309.

5 - Hill, Z.D. and Mac Carthy, P. (1986) J. Chem. Educ., 63(2), 163-167.

6 - H-H Perkampus, UV-vis Spectroscopy and its Applications, Springer (Berlin), 1992, p. 142.

\section{Acknowledgements}

The authors are indebted to Drs. Schneider, Weber and Fischer (HoffmannLa Roche, Basel, Switzerland) for providing them with samples of vitamin $D_{3}$ and its hydroxylated derivatives. 